\title{
KARAKTERISASI ISOLAT Fusicoccum (Crous. S dan Wingf. M.J) PADA KARET (Hevea brasiliensis) SECARA MORFOLOGI DAN TEKNIK POLYMERASE CHAIN REACTION
}

\author{
Characterization of Fusicoccum (Crous. S and Wingf. M.J) Isolates on Rubber (Hevea
} brasiliensis) through Morphologically and Polymerase Chain Reaction Technique

\author{
Yudiarto SARSONO ${ }^{1}$, Dwi SUGIPRIHATINI ${ }^{1}$, Tuti MURDIATI ${ }^{1}$, \\ Masayun Eka MAYLANDARI ${ }^{1}$, dan Tri Rapani FEBBIYANTI ${ }^{2 *}$ \\ ${ }^{1}$ Balai Besar Uji Standar Karantina Pertanian \\ Badan Karantina Pertanian - Kementerian Pertanian \\ Jalan Pemuda Nomor 64 Kav 16-17 Rawamangun \\ Jakarta Timur 13220 DKI Jakarta \\ ${ }^{2}$ Pusat Penelitian Karet Sembawa \\ Jalan Raya Palembang - Pangkalan Balai KM 29 \\ Sembawa, Banyuasin 30953, Sumatera Selatan \\ *Email : trifebbi@yahoo.com
}

Diterima : 24 Juli 2020 / Disetujui : 21 Desember 2020

\begin{abstract}
Fusicoccum is one of the causes ofleaf fall (leaf blight) in rubber plants. This disease has occurred in Johor Peninsular Malaysia rubber plantation in 2010, caused by the fungus Neofusicoccum ribis. Agricultural Quarantine as a Focal Point of the National Plant Protection Organization has an interest in ensuring the fungus that causes leaf blight on rubber plants and taking action to prevent entry and/or spread of Neofusicoccum ribis classified as Plant Pest Organisms (OPTK) A2 Group. Therefore, Agricultural Quarantine Agency through Center for Diagnostic Standard of Agricultural Quarantine in collaboration with Indonesian Rubber Research Institute Sembawa and the Indonesian Institute of Science Bogor tried to develop a test method to identify the fungus that causes Fusicoccum leaffall disease in the rubber plantation for quarantine purpose. The purpose of this study was to characterize the pathogens that cause Fusicoccum leaf fall disease morphologically. Morphological examination results directly on the leaves of symptomatic rubber leaves fall, showed Neofusicoccum fungi. PCR testing by using Universal ITS1/ITS4 Primers and continued with Spesific Primer BOT15/BOT16 obtained Neofusicoccum umdonicola and Neofusicoccum parvum, hereinafter referred
\end{abstract}

as Neofusicoccum compelex with each similarity were $99.66 \%$ and $97.08 \%$.

Keywords: Disease; Fusicoccum; leaf fall; morphology; Neofusicoccum; rubber

Abstrak
Fusicoccum merupakan salah satu
penyebab penyakit gugur (hawar) daun pada
tanaman karet. Penyakit ini pernah terjadi
di pertanaman karet Johor Peninsular
Malaysia pada tahun 2010, yang disebabkan
oleh cendawan Neofusicoccum ribis.
Karantina Pertanian sebagai Focal Point
bagian dari Organisasi Perlindungan
Tumbuhan Nasional berkepentingan
untuk memastikan cendawan penyebab
penyakit hawar daun pada tanaman karet
dan melakukan tindakan untuk mencegah
masuk dan/atau tersebarnya cendawan
Neofusicoccum ribis yang dikelompokan
sebagai Organisme Pengganggu Tumbuhan
(OPTK) A2 golongan I. Oleh karena itu,
Karantina Pertanian melalui Balai Besar Uji
Standar Mutu Karantina Pertanian bekerja
sama dengan Pusat Penelitian Karet
Sembawa serta Badan Pengkajian dan
Penerapan Teknologi Lembaga Ilmu

\section{Abstrak} penyebab penyakit gugur (hawar) daun pada tanaman karet. Penyakit ini pernah terjadi di pertanaman karet Johor Peninsular Malaysia pada tahun 2010, yang disebabkan Karantina Pertanian sebagai Focal Point bagian dari Organisasi Perlindungan Tumbuhan Nasional berkepentingan untuk memastikan cendawan penyebab penyakit hawar daun pada tanaman karet dan melakukan tindakan untuk mencegah masuk dan/atau tersebarnya cendawan Neofusicoccum ribis yang dikelompokan sebagai Organisme Pengganggu Tumbuhan PTK) A2 golongan I. Oleh karena itu, Standar Mutu Karantina Pertanian bekerja Sembawa serta Badan Pengkajian dan Penerapan Teknologi Lembaga Ilmu 
Pengetahuan Indonesia (LIPI) - Bogor mencoba mengembangkan metode uji dalam mengidentifikasi cendawan penyebab penyakit gugur daun Fusicoccum pada tanaman karet untuk keperluan karantina. Tujuan penelitian ini mengkarakterisasi patogen penyebab penyakit gugur daun Fusicoccum secara morfologi. Hasil pemeriksaan morfologi secara langsung terhadap daun karet bergejala gugur daun diperoleh jenis cendawan Neofusicoccum dan hasil pengujian PCR dengan menggunakan primer ITS1/ITS4 universal dan dilanjutkan dengan Primer BOT15/BOT16, diperoleh Neofusicoccum umdonicola dan Neofusicoccum parvum yang selanjutnya disebut sebagai Neofusicoccum complex dengan masing-masing tingkat kekerabatan $99,66 \%$ dan $97,08 \%$.

Kata kunci : Fusicoccum; gugur daun; karet; morfologi; Neofusicoccum; penyakit

\section{PENDAHULUAN}

Tanaman karet (Hevea bresiliensis) termasuk dalam famili Euphorbiaceae dari genus Hevea (Dornelas \& Rodriguez, 2005). Terdapat beberapa sentra produksi tanaman karet di Indonesia, antara lain Provinsi Sumatra Selatan, Sumatra Utara, Riau, Jambi dan Kalimantan Barat (Badan Pusat Statistik [BPS], 2018) dengan luas total 3,11 Juta Ha. Diantara provinsi tersebut, Sumatera Selatan merupakan penghasil lateks terbesar, yaitu 33,41\% (991,000 ribu ton) dari total produksi Nasional (BPS, 2018), kemudian produksi lateks Indonesia menduduki peringkat ke lima sebagai penyumbang devisa terbesar dari sektor non migas yaitu sebesar 2,742 ton atau setara dengan USD 3.836,7 juta (BPS, 2018). Hal tersebut menempatkan Indonesia sebagai produsen karet terbesar kedua di dunia setelah Thailand (BPS, 2018).

Rendahnya produksi karet rakyat disebabkan oleh berbagai faktor, diantaranya adanya gangguan dari berbagai penyakit (Basuki, 1982). Penyakit tanaman dapat menimbulkan hambatan pada pertumbuhan dan kerusakan pada bagian atau organ tanaman, penurunan hasil secara langsung atau kematian tanaman secara tidak langsung (Soepadmo, 1980). Penyakit tanaman karet tersebar di perkebunan karet Indonesia dengan menimbulkan kerusakan yang berbeda menurut lokasi kebun dan waktu yang berbeda.

Salah satu penyakit daun yang keberadaannya mulai meningkat di beberapa pertanaman karet yaitu penyakit hawar daun (Leaf Blight) Fusicoccum (Junaidi et al., 2018; Febbiyanti et al., 2018 ). Penyakit ini dilaporkan pernah terjadi pada awal 1987. Penyakit yang disebut dengan "menyerupai antraknos Colletotrichum" dilaporkan menyerang 60\% TBM umur 4 tahun di daerah $50 \mathrm{~m}$ di atas permukaan tanah di negara bagian Johor, Semenanjung Malaysia. Jenis klon yang terinfeksi yaitu klon RRIM 600, PR 261, PB 260, PB 255 dan PB 217 (Radziah \& Chee, 1989; Amponsah, 2010). Kemudian tahun 2010, penyakit yang disebabkan oleh Neofusicoccum sp ini kembali dilaporkan terjadi di Penisular Malaysia, menyerang tiga wilayah yaitu Selangor, Perak, dan Johor (Ngobisa et al., 2012; Ngobisa et al., 2013).

Di Indonesia, penyakit dengan gejala yang serupa pernah terjadi di Kebun Percobaan Balai Penelitian Sungei Putih, Sumatera Utara tahun 2013 yang menyerang klon IRR 117, tetapi belum menimbulkan kerugian yang berarti. Junaidi et al. (2018) melaporkan bahwa penyakit ini kembali terjadi di Balai Penelitian Sungei Putih, Medan, Sumatera Utara. Penyakit ini didominasi oleh patogen Colletotrichum dan Fusicoccum. Pada tanaman karet, patogen Neofusicoccum ribis dikelompokan sebagai Organisme Pengganggu Tumbuhan (OPTK) A2 golongan I.

Menurut Peraturan Menteri Pertanian Nomor 31 Tahun 2018, Neofusicoccum ribis pada tanaman karet keberadaanya masih sangat terbatas dan diusahakan untuk tidak menyebar ke wilayah sentra karet lainnya di Indonesia. Oleh karena itu, perlu dipastikan bahwa patogen penyebab kejadian penyakit gugur 
daun Fusicoccum yang dilaporkan terjadi di wilayah Sumatera Utara dan Sumatera Selatan. Untuk dapat melaksanakan hal tersebut, Badan Karantina Pertanian melalui Balai Besar Uji Standar Mutu Karantina Pertanian bekerja sama dengan Pusat Penelitian Karet Sembawa serta Badan Pengkajian dan Penerapan Teknologi Lembaga Ilmu Pengetahuan Indonesia (LIPI), Bogor mencoba mengembangkan metode uji dalam mengidentifikasi cendawan penyebab penyakit gugur daun Fusicoccum pada tanaman karet untuk keperluan karantina. Tujuan penelitian ini adalah untuk mengkarakterisasi patogen penyebab penyakit gugur daun Fusicoccum secara morfologi dan deteksi dengan metode Polymerase Chain Reaction (PCR).

\section{BAHAN DAN METODE}

Kegiatan pengembangan metode uji deteksi dan identifikasi cendawan pada tanaman karet dilaksanakan pada bulan April hingga Desember 2019 di Laboratorium Mikologi dan Biomolekuler Karantina Tumbuhan, Balai Besar Uji Standar Karantina Pertanian (BBUSKP) Jakarta dan Badan Pengkajian dan Penerapan Teknologi, Lembaga Ilmu Pengetahuan Indonesia (LIPI) Bogor. Isolat Fusicoccum disediakan oleh Pusat Penelitian Karet Sembawa. Bahan yang digunakan yaitu sampel berupa daun karet bergejala gugur daun dan kultur murni cendawan patogen penyebab gugur daun dalam media agar kentang sukrosa. Sampel tersebut diambil dari klon BPM24 yang diperoleh dari Pusat Penelitian Karet Sembawa. Bahan pendukung lain terdiri atas Primer ITS1/ITS4, primer BOT15/16 Spesifik, marker $100 \mathrm{bp}$ dan $1 \mathrm{~kb}$, Master mix Green TAE 1x, Etidium bromide, Agar ros, Aquades steril, seire atau lactofenol blue, ch lorok, objek dan cover glass, kertas blotter, tiseu, kutex, kertas label, Alkohol $70 \%$, spiritus. Alat digunakan dalam penelitian meliputi mikroskop stereo, mikroskop, nampan, laminar air flow, biosafety cabinet, heat block, timbangan, sentrigufe, mesin PCR, Geldoc, alat elektroforesis, mikropipet, mikro alu, jarum inikulasi, pipet, gunting, cutter, lampu spiritus.
Me tode Pengujian Morfologi
(Karakteristik Morfologi dan Kultur)

\section{Pengujian Secara Langsung (Dirrect Inspection)}

Seluruh sampel daun karet bergejala diperiksa secara langsung dengan menggunakan mikroskop stereo untuk melihat ada atau tidaknya hifa, konida, tubuh buah (pycnidia) dan sorus. Semua cendawan yang ditemukan dibuat preparat pada objek gelas dengan setetes larutan siere dan ditutup dengan cover gelas. Preparat tersebut kemudian diidentifikasi secara morfologi. Hasil identifikasi selanjutnya didokumentasikan dalam bentuk foto.

\section{Pengujian Dengan Menggunakan Metode Kertas Saring (Blotter Test)}

Seluruh sampel daun karet bergejala hawar dibilas air biasa yang mengalir sebanyak 1 kali, dipotong kecil-kecil, direndam klorok 1\% ( $\pm 1-2$ menit) dan dicuci dengan air akuades steril. Sampel kemudian diletakan dalam cawan petri yang berisi kertas saring yang telah dilembabkan dengan akuades steril. Selanjutnya diletakan dalam ruang inkubasi pada suhu kamar selama \pm 7-14 hari di bawah penyinaran Near Ultra Violet (NUV) 12 jam terang-gelap. Setelah diinkubasi, seluruh sampel daun karet bergejala hawar dalam cawan petri di periksa untuk melihat ada atau tidaknya hifa, konida, tubuh buah (pycnidia) dan sorus. Semua cendawan yang ditemukan di buat preparat pada objek gelas dengan setetes larutan siere dan ditutup cover gelas. Preparat tersebut kemudian di identifikasi secara morfologi dan morfometri dengan menggunkan mikrokop kompon. Hasil identifikasi selanjutnya didokumentasikan dalam bentuk foto.

\section{Pengujian Dengan Menggunakan Kultur (Media Agar Kentang Dekstrosa, PDA)}

Seluruh sampel daun karet bergejala hawar dibilas air biasa yang mengalir, direndam klorok 1\% ( $\pm 1-2$ menit), dicuci dengan akuades steril dan dikeringanginkan. Selanjutnya sampel diperiksa secara langsung menggunakan mikroskop stereo untuk melihat ada atau 
tidaknya hifa, konida, tubuh buah (pycnidia) dan sorus. Semua cendawan yang ditemukan (dalam bentuk hifa, konida, tubuh buah (pycnidia dan sorus) dibiakan dalam media PDA. Selanjutnya diletakan dalam ruang inkubasi pada temperatur sejuk selama \pm 7-14 hari di bawah penyinaran Near Ultra Violet (NUV) 12 jam terang-gelap. Hasil kultur diperiksa dan didokumentasikan dan dikarakterisasi morfologinya menggunakan buku acuan menurut Rayachhetry et al. (1996), Slippers et al. (2004), Pavlic et al. (2009), Amponsah (2010), Begoude et al. (2010), Phillips et al. (2013), dan Sakalidis et al. (2013).

\section{Metode Pengujian Polymerase Chain Reaction (PCR).}

\section{Ekstraksi DNA}

Pengujian PCR dilakukan terhadap isolat cendawan target yang diduga Neofusicoccum ribis. Isolat diperoleh dari biakan murni setiap klon berumur 10 hari. Dari isolat tersebut sebanyak enam blok miselium yang ditumbuhkan pada temperatur $26^{\circ} \mathrm{C}$ dipindahkan ke dalam labu erlemeyer berisi $50 \mathrm{~mL}$ agar Broth Kentang Dekstrosa dan digoyang pada $60 \mathrm{rpm}$ dalam suhu kamar selama 5 hari. Kemudian miselia disaring menggunakan ketas saring dan dicuci dua kali dengan akuades steril, dibiarkan mengering selanjutnya diambil $250 \mathrm{mg}$ dan digerus dengan mikro alu dalam tabung kerucut mikro centrifuge 1,5 mL dengan penambahan nitrogen cair. Ekstraksi DNA dilakukan menggunakan protokol yang disarankan oleh Sambrook et al., (1989) dan Birren dan Lai (1994). Setelah memperoleh DNA cendawan maka dilakukan pengujian menggunakan PCR Primer Universal ITS-1 dan ITS-4 (White et al., 1990) dan dilanjutkan dengan primer BOT15/BOT16. Primer BOT merupakan p ri m e r s e sifik kelu a g a Botryosphaeriaceae dan Neofusicoccum ribis termasuk dalam golongan ini. Dengan mengikuti komposisi pencampuran (dalam satuan volume) untuk reaksi PCR sebagai berikut $1 \mu \mathrm{L}$ Primer ITS 1 Forward, $1 \mu \mathrm{L}$ Primer ITS 4 Reserve, $1 \mu \mathrm{L}$ Template (DNA), 12,5 $\mu \mathrm{L}$ Master Mix, dan 9,5 $\mu \mathrm{L}$ Nuclease Free Water, sehingga volume total pencampuran adalah $25 \mu \mathrm{L}$.

Amplifikasi dilakukan menggunakan PCR pada volume total $25 \mathrm{~mL}$ dalam siklus. 1 siklus pada $94^{\circ} \mathrm{C}$ selam 3 menit terdiri dari 35 Siklus Denaturasi $94^{\circ} \mathrm{C}, 1$ menit, penempelan primer $60^{\circ} \mathrm{C}, 1$ menit, pemanjangan primer $72^{\circ} \mathrm{C}, 2$ menit. 1 Siklus pemanjangan akhir $72{ }^{\circ} \mathrm{C}, 10$ menit, siklus terakhir $4^{\circ} \mathrm{C}$. Hasil PCR divisualisasi pada gel agaros $1 \%$ dalam larutan buffer TAE $1 \times$ $40 \mathrm{mM}$ Tris, $20 \mathrm{mM}$ asam asetat, dan $1 \mathrm{mM}$ EDTA pada 80 Volt selama 45 menit dalam suhu ruang. Pembuatan agaros mengikuti rumus $1 \% \mathrm{x}$ kapasitas cetakan gel agaros (mL). Untuk mempermudah visualisasi, gel diberikan pewarnaan dengan cara merendam dalam etidium bromide \pm 30-60 menit), dan pita divisualisasikan di bawah sinar UV dan difoto menggunakan sistem dokumentasi gel (gel doc). Ukuran fragmen DNA yang diperkuat ditentukan menggunakan penanda berat molekul (GeneRuler 100 bp DNA Ladder (Fermentas, USA)).

\section{Sekuensing DNA dan Analisis}

Sekuensing dari hasil produk PCR dilakukan ke pihak ketiga (First Base di Kuala Lumpur, Malaysia) menggunakan metode Sanger et al. (1977). Urutan sekuen

Tabel 1. Susunan basa primer yang digunakan dalam penelitian Table 1. Prime base arrangement which was used in the experiment

\begin{tabular}{ll}
\hline $\begin{array}{l}\text { Primer } \\
\text { Prime }\end{array}$ & $\begin{array}{l}\text { Susunan basa } \\
\text { Base arrangement }\end{array}$ \\
\hline ITS1 & 5'-TCC GTA GGT GAA CC T GCG G-3' \\
ITS4 & 5'-TCC TCC GCT TAT TGA TAT GC-3' \\
BO T15 & 5'-CTG ACT TGT GAC GCC GG C TC-3 ' \\
BOT16 & 5'-CAA CC T GCT CAG CAA GCG AC-3' \\
\hline
\end{tabular}


fragmen gen yang diperoleh selanjutnya dianalisis dengan program BLAST pada website www.ncbi.nlm.nih.gov dengan menggunakan program MEGA 6 (Tamura et al., 2013).

\section{HASIL DAN PEMBAHASAN}

\section{Karakter Morfologi}

Deskripsi morfologi dari Fusicoccum mengikuti kunci identifikasi menurut Pavlic (2009) dan beberapa referensi lainnya. Cendawan ini memiliki askostroma erumpent melalui permukaan kulit daun, diameter 100-400 $\mu \mathrm{m}$. Askomata pseudothecial, membentuk kumpulan botryose hingga 5-50, globose dengan lubang pengeluaran askospora di tengah dengan papillate atau tidak, cokelat sampai kehitaman, 175-250 $\mu \mathrm{m}$, dinding pseudothecial terdiri dari 5-15 lapisan tekstur angularis, bagian luar sel cokelat atau cokelat gelap, bagian dalam 2-4 lapisan sel-sel hialin yang melapisi lokus. Askus bitunicate, clavate, 8-askospora, 80-120 × 17-20 $\mu \mathrm{m}$. Pseudoparafisis filiform, bersekat, jarang bercabang, lebar 2-4 $\mu \mathrm{m}$. Askospora fusoid, sering membulat di ujungnya kemudian secara luas ellips, hialin, 1 sel, halus dengan isi granular, biseriate pada ascus, (14-18)- (23-27) × (6-8)-10 $\mu \mathrm{m}$ (rerata dari 80 askospora $=20,5 \times 7,1 \mu \mathrm{m})$. Pseudotesium subepidermal, bulat, diameter $230 \mu \mathrm{m}$, dinding askokarp dibentuk oleh selsel dari tekstur angularis, silindris, bertangkai pendek, 63-68 x 13-14 um, askospora ellips sampai ellips tidak teratur, hialin sampai kekuningan, 20-25,5 x 6-8,5 $\mu \mathrm{m}$. Konidia yang diproduksi dengan daun pinus pada awalnya hialin dan aseptat dan menjadi cokelat muda dan 1 - atau 2-septate seiring bertambahnya usia. Selain itu, konidia berbentuk ellipsoidal dengan ujung membulat bundar dan bagian dasar terpotong dengan ukuran 16,5-24,0 × 3,5$6,5 \mu \mathrm{m}$ dan rasio $\mathrm{P} / \mathrm{L}$ rata-rata 3,9 $\mu \mathrm{m}$. Tidak ada struktur teleomorphyang terbentuk.
Isolasi cendawan tumbuh cepat dengan miselium putih yang berubah menjadi abu-abu kehijauan gelap atau abuabu dalam beberapa hari. Koloni ditandai oleh pertumbuhan koloni cepat yaitu 16,5$17,0 \mathrm{~mm} / \mathrm{hari}$, yang menutupi cawan petri setelah 5 hari. Selain itu, miselium putih berbulu menjadi sedikit kuning atau kecoklatan di bagian bawah setelah 4 hari. Pada hari ke-5, pusat-pusat menjadi cokelat terang; miselium putih berbulu hanya pada bagian tepi. Piknidida muncul dalam 7 -12 hari pada Potato Dextrosa Agar.

\section{Karakter Molekuler Dengan Analisa Polymerase Chain Reaction (PCR)}

Hasi1 amplifikasi ITS $1 /$ ITS 4 menunjukkan isolat hasil karakter morfologi Fusicoccum pada garis ke-7 memiliki pita DNA berkisar antara 525 hingga 550 basepare (bp) dalam marker penanda $1 \mathrm{~kb}$ sebagai pembanding. Hasil analisis PCR selengkapnya tersaji dalam Gambar 1. Selain menggunakan primer ITS 1 dan ITS 4, pada isolat target juga dilakukan analisis PCR dengan primer spesifik yaitu primer BOT dengan tahapan dan cara yang sama pada primer sebelumnya. Hasil amplifikasi isolat Fusicoccum menggunakan primer BOT memiliki kisaran pita DNA antara 340 bp sampai dengan 350 bp dalam marker penanda 100 basepare, selengkapnya tersaji pada Gambar 2.

Pengujian PCR dilanjutkan pada tahapan skuensing DNA. Hasil skuensing produk PCR selanjutnya dibaca dan diurutkan menggunakan program MEGA versi 6.0 (Tamura et al., 2013). Hasil analisis skuensing DNA tersebut disajikan pada Tabel 2.

Dari perbandingan di atas diperoleh nama jenis cendawan dari isolat uji. Berdasarkan hasil terlihat isolat uji memiliki kekerabatan lebih ke arah Neofusicoccum umdonicola strain CBS 12365 dengan homolog ikatan basa mencapai 99,66\% dan 


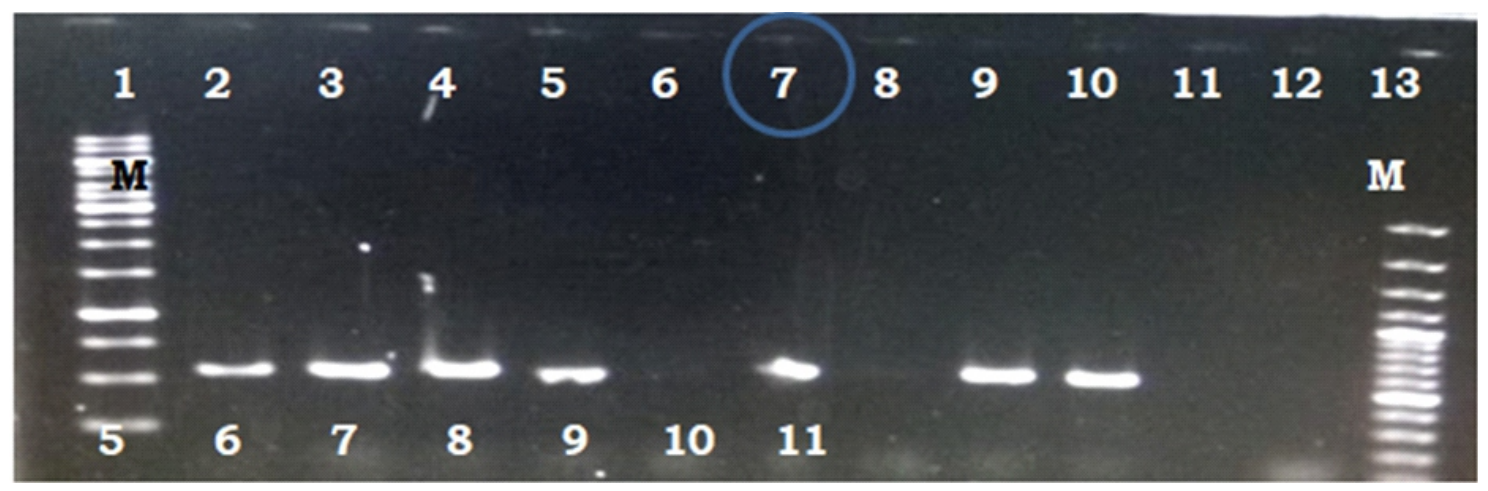

Gambar 1. Hasil amplifikasi dengan menggunakan primer ITS1/ITS4 pada gel agarose 1,2\%, 100 volt selama 45 menit. Garis 1 berisi marker 100 bp, garis ke 7 berisi isolat uji, garis ke 10 Kontrol positif Fox P, Kontrol positif, Fox J; Garis ke 12 Kontrol negatif; dan garis ke 13 berisi marker $1 \mathrm{~kb}$

Figure 1. The amplification results used ITS1 / ITS4 primer on 1.2\% agarose gel, 100 volts for 45 minutes. Line 1 contains marker $100 \mathrm{bp}$, line 7 contains target isolate, line 10 Positive control of Fox P, positive control, Fox J; Line 12 Negative control; and the 13 th line contains a $1 \mathrm{~kb}$ marker

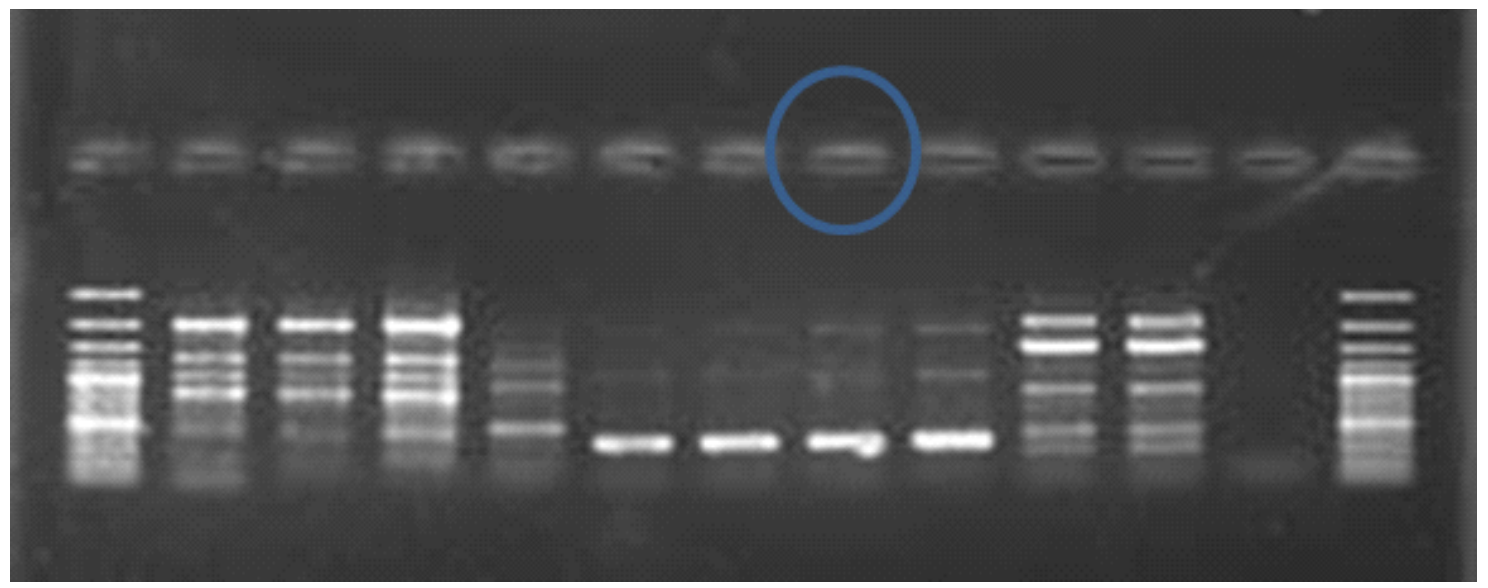

Gambar 2. Hasil amplifikasi menggunakan primer spesifik BOT15/BOT16 pada gel agarose $1,2 \%, 100$ volt selama 45 menit. Garis 2 : marker 100 bp; garis ke 8 berisi isolat uji, Kontrol positif Fox P, Kontrol positif Fox J; garis 12 berisi kontrol negatif dan garis ke 13 berisi marker $100 \mathrm{bp}$

Figure 2. The results of the amplification used BOT15 / BOT16 specific primers on agarose gel 1.2\%, 100 volts for 45 minutes. Line 2: $100 \mathrm{bp}$ marker; the 8th line contains target isolate, Fox P positive control, Fox J positive control; line 12 contains negative controls and the 13th line contains $100 \mathrm{bp}$ markers 
Tabel 2. Hasil penyejajaran DNA yang tersedia dalam data GenBank NCBI

Table 2. Result of DNA sequence alignment available in NCBI GenBank data

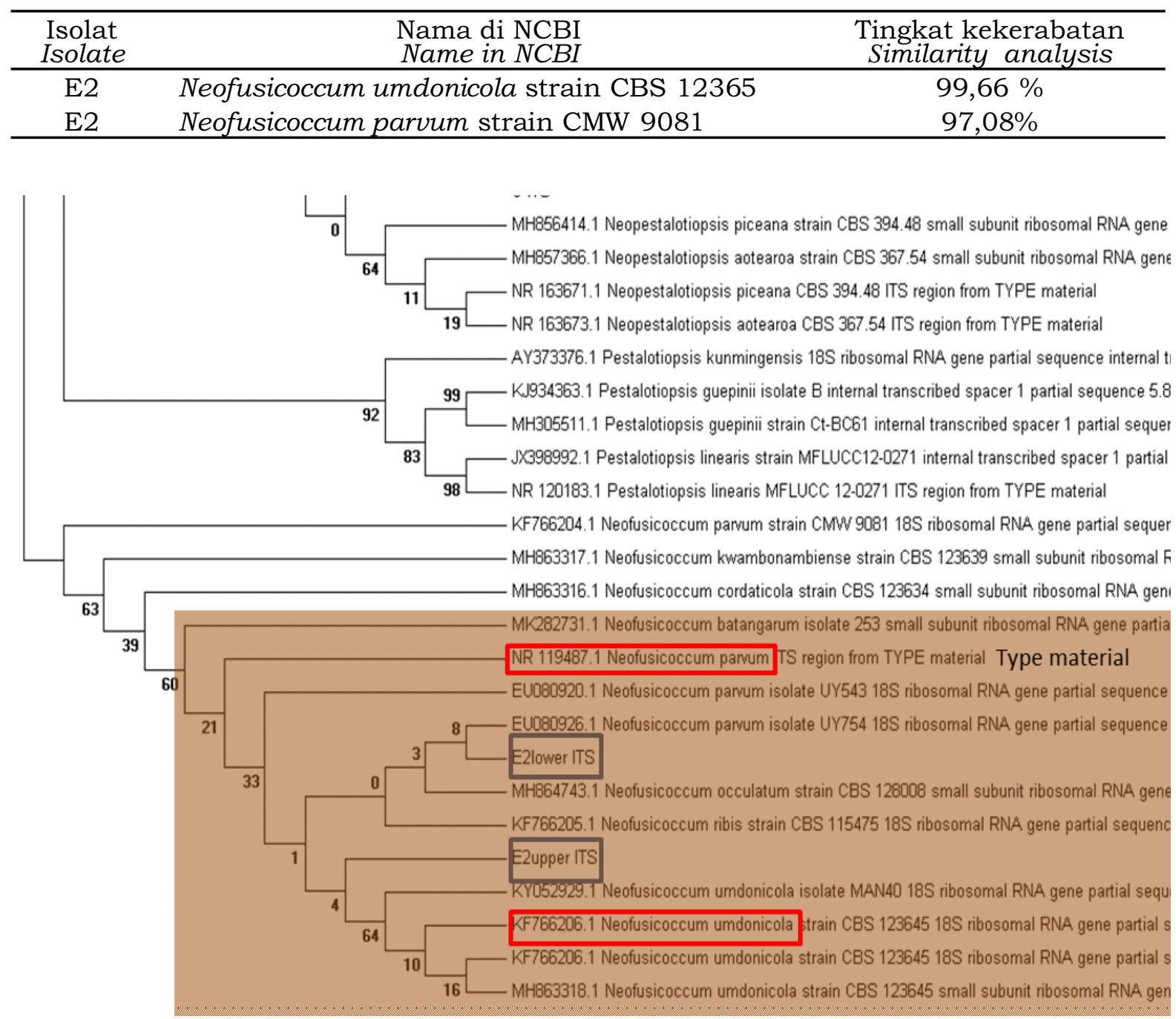

Gambar 3. Pohon phylogenetic isolat Neofusicoccum parvum dan Neofusicoccum umdonicola menggunakan analisa Maximum Likelyhood

Gambar 3. Phylogenetic tree of Neofusicoccum parvum and Neofusicoccum umdonicola isolates by using Maximum Likelyhood analysis 
Neofusicoccum parvum dengan tingkat kekerabatan 97,08\% dan keduanya disebut sebagai Neofusicoccum complex karena memiliki hasil spesies yang berbeda dengan menggunakan dua primer yang berbeda (ITS dan BOT). Apabila ingin mendapatkan satu nama spesies yang pasti, maka harus menggunakan primer jenis beta tubulin atau Primer Elongation Factor (EF) yang dapat memberikan satu nama spesies. Selanjutnya hasil dari perbandingan di atas divisualisasi menjadi pohon phylogenetic dengan menggunakan ClustalW2. Pohon phylogenetic dibuat untuk mempermudah penilaian dan analisis kekerabatan, dengan gabungan hubungan kekerabatan yang berdekatan.

\section{KESIMPULAN}

Berdasarkan pengujian isolat patogen gugur daun Fusicoccum yang dilaporkan terjadi di wilayah Sumatera Utara dan Sumatera Selatan dengan menggunakan karakter morfologi dan metode Polymerase Chain Reaction (PCR) dapat diketahui adalah patogen Neofusicoccum umdonicola dan Neofusicoccum parvum. Kedua patogen ini selanjutnya disebut sebagai Neofusicoccum complex dengan masing-masing tingkat kekerabatan 99,66\% dan 97,08\%.

\section{UCAPAN TERIMA KASIH}

Ucapan terima kasih disampaikan kepada Kepala Balai Besar Uji Standar Karantina Pertanian, Bapak drh. Sriyanto, M.Si., Ph.D atas dukungan penelitian; Kepala Pusat Penelitian Karet Sembawa Palembang dan Peneliti Proteksi Pusat Penelitian Karet serta Badan Penelitian dan Pengembangan Teknologi-Lembaga Ilmu Pengetahuan Indonesia, Bapak Imam Hidayat Ph.D dan Ibu Dr.Marlina Ardiyanti, serta banyak pihak terkait yang tidak dapat disebutkan satu persatu hingga terwujudnya kajian penulisan ini.

\section{DAFTAR PUSTAKA}

Amponsah, N.T. (2010). Epidemiology of botryosphaeriaceous species associated with grapevines in New Zealand. [Thesis]. New Zealand: Lincoln University-christchurch.

Badan Pusat Statistik. (2018). Statisik Karet Indonesia. Jakarta, Indonesia: BPS.

Basuki. (1982). Penyakit dan Gangguan Pada Tanaman Karet. Tanjung Morawa, Indonesia: Pusat Penelitian dan Pengembangan Perkebunan.

Begoude, B.A.D., Slippers, B., Wingfield, M.J., \& Roux, J. $\left(\begin{array}{llll}2 & 0 & 1 & 0\end{array}\right)$. Botryosphaeriaceae associated with Terminalia catappa in Cameroon, South Africa and Madagascar. Mycol. Progress, 9, 101-123. https://doi.org/ $10.1007 / \mathrm{s} 11557-009-0622-4$

Birren, B., \& Lai, E. (1994). Rapid pulsed field separation of DNA molecules up to $250 \mathrm{~kb}$. Nucleic Acids Research, 22(4), 5366-5370. https://dx.doi.org/ 10.1093nar22.24.5366

Dornelas, M.C., \& Rodriguez, A.P.M. (2005). The rubber tree (Hevea brasiliensis Muell. Arg.) homologue of the LEAFY/FLORICAULA gene is preferentially expressed in both male and female floral meristems. Journal of Experimental Botany, 56(417), 1965-1974. https://doi.org/10.1093 /jxb/eri194

Febbiyanti, T.R., Alchemi, P.J.K., Fairuza, Z., \& Herlinawati, E. (2018). The outbreak of Fusicoccum leaf disease in Indonesia and the potential yield loss. International Plant Protection Workshop. Palembang, Indonesia: Balai Penelitian Sembawa. 
Junaidi., Tistama, R., Atminingsih., Fairuzah, Z., Rachmawan, A., Darojat, M.R., \& Andriyanto, M. (2018). Fenomena gugur daun sekunder di Wilayah Sumatera Utara dan pengaruhnya terhadap produksi karet. Warta Perkaretan, 37(1), 1-16. https://doi.org/ 10.22302/ppk.wp.v3 $7 \mathrm{i} 1.441$

Ngobisa. N.A.I.C., Abidin, M.A.Z., Wong, M.Y., \& Mahyudian, M.M. (2012). Cultural and morphological characterisation of Fusicoccum sp, the causal agent of rubber (Hevea brasiliensis) leaf blight in Malaysia. Journal Rubber Research, 15(1), 64-79.

Ngobisa. N.A.I.C., Abidin, M.A.Z., Wong, M.Y., \& Noordin, M.W.D.W. (2013). Neofusicoccum ribis associated with leaf blight on rubber (Hevea brasiliensis) in Peninsular Malaysia. The Plant Phatology Journal, 29(1), 1016. https://dx.doi.org/10.5423 \%2FPPJ.OA.07.2012.0110

Pavlic, D., Slippers, B., Coutinho, T.A., \& Wingfield, M.J. (2009). Molecular and phenotypic characterization of the tree phylogenetic species discovered within the Neofusicoccum parvum/N. ribis complex. Mycologia, 101(5), 636-647. https://doi.org/10.3852/08-193

Phillips. A.J.L., Alves, A., Abdollahzadeh, J., Slippers, B., Wingfield, M.J., Groenewald, J.Z., \& Crous, P.W. (2013). The Botryosphaeriaceae: genera and species known from culture. Studies in Mycology, 76(1), 51-167. ht t p s:// doi.org/ $10.3114 / \operatorname{sim} 0021$

Radziah, N.Z., \& Chee, K.H. (1989). A new foliar disease of rubber. Plant Pathology, 38, 293-296. https:// doi.org/10.1111/j.1365-3059.1989. tb02147.x
Rayachhetry, M.B., Blakeslee, G.M., Webb, R.S., \& Kimbrough, J.W. (1996). Characteristics of the Fusicoccum anamorph of Botryosphaeria ribis, a potential biological control agent for Melaleuca quinquenervia in South Florida. Mycologia, 88(2), 239-248. https:/ / doi.org/10.1080/00275514.1 996.12026649

Sakalidis. M.L., Slippers, B., Wingfield, B.D., Hardy, G.E.St.J., \& Burgess, T.I. (2013). The challenge of understanding the origin, pathways and extent of fungal invasions: Global populations of the Neofusicoccum parvum - N. ribis species complex. Diversity and Distributions, 19, 873-883. https://doi.org/10.1111/ddi.12030

Sambrook, J., Fritschi, E.F., \& Maniatis. T. (1989). Molecular Cloning: A Laboratory Manual. New York, US: Cold Spring Harbor Laboratory Press.

Sanger, F., Nicklen, S., \& Coulson, AR. (1977). DNA sequencing with chainterminating inhibitors. Proceedings National. Academic Science USA., 74(12), 54637. https://dx.doi.org/1 $0.1073 \% 2$ Fpnas.74.12.5463

Slippers, B., Burgess, T., Crous, P.W., Coutinho, T.A., Wingfield, B.D., \& Wingfield, M.J. (2004). Development of SSR markers for Botryosphaeria spp with Fusicoccum anamorphs. Molecular Ecology Notes, 4, 675-677. https://doi.org/10.1111/j.14718286.2004.00780.x

Soepadmo. (1980). Suatu pemikiran tentang pengendalian penyakit daun pada tanaman karet. Menara Perkebunan, 48(5), 147-154. 
Tamura, K., Stecher, G., Peterson, D., Filipski, A., \& Kumar, S. (2013). MEGA6: Molecular evolutionary genetics analysis version 6.0. Molecular Biology and Evolution, 30(12), 2725-2729. https://doi.org/ $10.1093 / \mathrm{molbev} / \mathrm{mst} 197$
White, T.J., Bruns, T., Lee, S., \& Talor, J. (1990). Amplification and direct sequencing of fungal ribosomal RNA genes for phylogenetics. In Innis, M.A., Gelfand, D.H., Snisky, J.J., \& White, T. J. PCR Protocols, a Guide to Methods and Applications. New York, USA: Academic Press. 